\title{
Review \\ Nondairy Probiotic Products: Functional Foods That Require More Attention
}

\author{
Kübra Küçükgöz (D) and Monika Trząskowska *D
}

check for updates

Citation: Küçükgöz, K.; Trząskowska, M. Nondairy Probiotic Products:

Functional Foods That Require More

Attention. Nutrients 2022, 14, 753.

https://doi.org/10.3390/

nu14040753

Academic Editors: Valentina Melini and Maurizio Ruzzi

Received: 24 December 2021

Accepted: 9 February 2022

Published: 10 February 2022

Publisher's Note: MDPI stays neutral with regard to jurisdictional claims in published maps and institutional affiliations.

Copyright: (C) 2022 by the authors. Licensee MDPI, Basel, Switzerland. This article is an open access article distributed under the terms and conditions of the Creative Commons Attribution (CC BY) license (https:// creativecommons.org/licenses/by/ $4.0 /)$.
Department of Food Gastronomy and Food Hygiene, Institute of Human Nutrition Sciences, Warsaw University of Life Sciences-SGGW, Nowoursynowska 159c St., 02-776 Warsaw, Poland; kubra_kucukgoz@sggw.edu.pl

* Correspondence: monika_trzaskowska@sggw.edu.pl

\begin{abstract}
The potential health benefits of probiotics have been illustrated by many studies. However, most functional foods containing probiotics are from dairy sources. This review provides an overview of potential strains and raw materials for nondairy probiotic products together with the role of its in vitro assessment. Probiotic-containing products from raw nondairy materials are known both in terms of quality and nutritional values. The sensory properties of raw plant-based materials are generally improved as a result of fermentation with probiotics. Increased market shares for plantbased probiotic products may also help to curb environmental challenges. The sustainability of this food results from reductions in land use, greenhouse gas emissions, and water use during production. Consuming nondairy probiotic food can be a personal step to contribute to climate change mitigation. Since some people cannot or do not want to eat dairy products, this creates a market gap in the supply of nutritious food. Therefore, the promotion and broader development of these foods are needed. Expanding our knowledge on how to best produce these functional foods and increasing our understanding of their in vivo behaviours are crucial. The latter may be efficiently achieved by utilizing available in vitro digestion systems that reliably recapitulate the in vivo situation without introducing any ethical concerns.
\end{abstract}

Keywords: fermentation; functional food; nondairy food; plant foods; probiotic; in vitro digestion

\section{Introduction}

Growing consumer interest in health and wellness also affects nutritional habits and food choices. Consumers' nutritional understanding has changed from only meeting their energy needs to also providing a healthy and balanced nutrition profile. Functional foods including probiotic-containing products belong to this diet category [1]. Consumers are also becoming more concerned about the sustainability of the food chain; thus, this encourages manufacturers to give importance to the development of such functional foods. The key to the successful marketing and acceptance of new foods depends on the concept of added value based on food quality and food functions [2]. The global probiotic food market is growing very quickly due to increasing consumer awareness about the impact of food on health. Today, probiotic products account for $60 \%$ to $70 \%$ of the total functional food market $[3,4]$.

Probiotics are a common ingredient in functional foods, as they confer health benefits when consumed in adequate amounts [5]. There are various health benefits associated with probiotic strains, including intestinal and nonintestinal effects. Intestinal benefits include the prevention of diarrhoea, the reduction in symptoms associated with inflammatory bowel disease, the prevention of gastrointestinal cancers, the alleviation of lactose intolerance, and a reduction in Helicobacter pylori infections [6]. Moreover, probiotics may play a role in the prevention and treatment of intestinal inflammatory disorders [7] such as Crohn's disease and pouchitis, and paediatric atopic disorders. The impact of using probiotics on bacterial infections and immunological conditions such as adult asthma, cancer, diabetes, and arthritis is unconfirmed in humans [7,8]. 
The intestinal microbiota is as a potential factor in pathophysiology and associated metabolic disorders. Studies investigating the effect of probiotic intake on serum lipids, cholesterol levels, and more recently on blood pressure and glucose regulation indicate that probiotics may also benefit these factors [9].

Additionally, supplementing pregnant mothers with probiotics impacts mother and infant metabolism and later health $[10,11]$. The above-mentioned advantages of probiotics justify the indepth research of nondairy probiotic products, encompassing strain selection and characteristics, functional food development, and health properties.

The purpose of this review is to draw attention to and provide an overview of potential strains and raw materials for the production of nondairy probiotic products, along with the role of in vitro evaluation of such functional foods to accelerate the research and development of this functional food category.

\section{Literature Search Methodology}

For this review, a literature search was conducted in the Web of Science, PubMed, Google Scholar, and ScienceDirect search engines with keywords "fermentation", "functional food", "nondairy food", "plant foods", "probiotic", and "in vitro digestion". All selected terms were used in one search.

The timeline for our literature survey was set from 2011 to 2021 (in January 2022). The article titles and abstracts were reviewed, and duplicates were removed. Only studies on probiotics and nondairy food products were considered for inclusion. The literature concerning animals was excluded. Eligible sources of evidence included research articles, review articles, short communications, and book chapters. Full articles with appropriate references were obtained, the full text was read, and they were evaluated for final inclusion. Additional studies with respect to our search terms were only used for limited and specific purposes.

\section{Potential Strains and Raw Materials for Nondairy Probiotics}

\subsection{Probiotic Strains and Viability Properties}

The benefits of probiotic products are related to the selection of probiotic strains and their survival. The functionality of probiotics is generally strain-dependent. Strains should be resistant to gastric acid and bile, and be safe for human consumption [12,13]. Furthermore, a food must contain an adequate number of viable bacteria to have probiotic properties [14]. The stages of probiotic food production affect probiotic microorganisms viability and stability. Microorganisms should also survive during processing, storage, handling, transport, and shelf life [4].

Due to these criteria and safety regulations, Lactobacillus, Streptococcus, Propionibacterium, Enterococcus, Pediococcus, and Saccharomyces can be used as probiotic microorganism sources for nondairy probiotic products [15].

Fermented nondairy food products can also be a source of probiotic bacteria. For example, bacterial strains isolated from cucumber and cabbage prepared by traditional methods have probiotic properties. Ten different Lactobacillus strains were isolated: L. johnsnonii K4, L. rhamnosus K3, L. brevis $(\mathrm{O} 22, \mathrm{O} 24)$, L. plantarum $(\mathrm{O} 19,020)$, and L. casei $(\mathrm{O} 12$, 013, 016, O18). Isolated strains were examined in gastrointestinal conditions to test safety for human consumption by in vitro experiment. Most of the isolated Lactobacillus strains could survive in gastrointestinal conditions and are safe for human consumption [12,13].

However, different raw materials play a specific role in bacterial growth, functionality, viability, and survival with their food matrix. Therefore, well-suited strains should be selected for each type of product [16-20]. Many studies have been conducted to incorporate microbes into different food matrices, some of which are discussed below.

Research has been undertaken to determine the suitability of tomato juice as a raw material for the production of probiotic juice by four lactic acid bacteria. Tomato juice was inoculated with probiotics such as L. acidophilus, L. casei, L. delbrueckii, and L. plantarum. The bacteria isolate fermented tomato juice from $\mathrm{pH} 4.1$ to 3.5 in $72 \mathrm{~h}$. They reached a viable cell population of more than $8 \log \mathrm{CFU} / \mathrm{mL}$ ( of $<5 \log \mathrm{CFU} / \mathrm{mL}$ ) after $48 \mathrm{~h}$ of fermentation at $30^{\circ} \mathrm{C}$ [18]. In other 
research, L. sanfranciscensis was added to tomato juice and stored for 4 weeks at $4{ }^{\circ} \mathrm{C}$. After storage, the number of surviving bacteria was determined and there was a decrease in probiotic viability. However, decreasing amount from 8 to $7.5 \log \mathrm{CFU} / \mathrm{mL}$ was still acceptable and showed that tomato juice is a possible carrier of probiotic L. sanfranciscensis [20].

Oats are important sources of beta-glucan, recognized as the most important functional component in cereal fibre. In addition, beta-glucan is known as a prebiotic as it stimulates the growth of some beneficial microorganisms in the colon [21,22]. Furthermore, betaglucan supports the viability of probiotic strains during cold storage [21-23]. In a study, the effects of beta-glucan obtained from oatmeal and modified beta-glucan samples obtained with xylanase treatment on the probiotic Bifidobacterium bifidum were investigated. While the two components had a significant effect on the growth of Bifidobacterium bifidum, the effect of modified beta-glucan was greater [22-24].

Beetroots have rich nutrient content and bioactive compounds [25,26]. Fermented beetroot with Lactobacillus bacteria had good biological viability and antimutagenic activity for up to 30 days at refrigerated storage [26]. Research about enriched ready-to-eat beetroot products with L. plantarum showed 8-9 log probiotic cells in $100 \mathrm{~g}$. In addition, probiotic viability was greater than $7 \log \mathrm{CFU} / \mathrm{g}$ after 21 days of storage at $4{ }^{\circ} \mathrm{C}$; these results showed that the beetroot food matrix is favourable for probiotic survival [27].

Research that focused on producing potentially probiotic orange juice showed that different microorganisms have different viability. L. rhamnosus and nettle (Urtica dioica L.) additions were used for production, while L. rhamnosus was able to remain above 6 log $\mathrm{CFU} / \mathrm{mL}$ at $4{ }^{\circ} \mathrm{C}$ storage for 28 days, but nettle could not improve the viability of the product [28].

Another study reported on orange juice with Bacillus coagulans GBI-30 6086 in animal models compared with yoghurt samples of the same probiotic. The probiotic orange juice food matrix adversely affected the functionality of probiotics in rats. The rats that had been fed the probiotic yoghurt group also showed higher gut bacterial diversity than that of orange juice [29].

Some features of the raw materials can cause the loss of viability of probiotic microorganisms such as natural antimicrobial compounds, acidity, diacetyl, and hydrogen peroxide [30].

Table 1 provides data on probiotic bacterial viability in different types of food.

\subsection{Properties and Environmental Concerns of Raw Nondairy Materials for Probiotic Products}

All over the world, most probiotic products are dairy-based. The increased health awareness of consumers and some health-related issues has led to the exploration of nondairy-based products. For example, plant-based alternative yoghurts are being developed and marketed in increasing numbers [40]. Statistical analysis shows that there are more than 380 types of probiotic products in the world, but $80 \%$ of these products are from dairy sources. Nondairy probiotic products with fruit and vegetable origins are very rare [5]. The lack of nondairy probiotic products means that various human groups do not benefit from functional foods containing probiotics. However, industry and people's interest in nondairy probiotic products is increasing for a variety of reasons [41]. The strongest drivers of nondairy products are vegetarianism, milk cholesterol content, lactose intolerance, and consumer interest in shelf diversity and sensory appeal. From the industry viewpoint, many manufacturers are seeking ways to create and increase value, which has further increased the product profile. However, a more compelling reason and the stronger driver is the emerging evidence of health benefits that can be acquired from a symbiotic relationship between plant components and probiotics, and gut commensals [42,43]. Nondairy products also contain more antioxidant phytochemicals such as phenolic acids, carotenoids, and flavonoids that have positive effects on oxidative stress in the body, prevent cell damage, and help to change the lipid metabolism and reduce obesity risk factors [43]. 
Table 1. Viability of probiotic bacteria in the different types of foods.

\begin{tabular}{|c|c|c|c|c|}
\hline Genus & Species & Product Type & Viability (log CFU per $\mathrm{mL}$ or $\mathrm{g})$ & References \\
\hline \multirow[t]{8}{*}{ Lactobacillus } & L. rhamnosus ATCC7469 & $\begin{array}{l}\text { Fruit-Based Product } \\
\text { Dried apple slices }\end{array}$ & $\begin{array}{c}1.0-3.0 \log \text { in slices dried by freezing } \\
\text { and a combination of air drying and } \\
\text { vacuum drying after } 120 \text { days storage } \\
\text { at } 25^{\circ} \mathrm{C} \text {, but higher viability of } \\
9.3-7.8 \log \text { was found at } 4^{\circ} \mathrm{C} \text { for } \\
180 \text { days. }\end{array}$ & {$[31]$} \\
\hline & $\begin{array}{l}\text { L. plantarum B2, } L \text {. } \\
\text { fermentum } \text { PBCC11. }\end{array}$ & $\begin{array}{l}\text { Fruit-Based Product } \\
\text { Fresh-cut cantaloupe }\end{array}$ & $\begin{array}{l}\text { L. plantarum }(8.1 \mathrm{log}) \text { and } L . \text { fermentum } \\
(7.8 \mathrm{log}) \text { after } 11 \text { days of storage at } 4{ }^{\circ} \mathrm{C}\end{array}$ & [32] \\
\hline & $\begin{array}{l}\text { L. helveticus } \\
76 \text { (Lh76) }\end{array}$ & $\begin{array}{l}\text { Fruit-Based Product } \\
\text { Kiwifruit juice }\end{array}$ & $\begin{array}{c}\text { Above } 9.0 \log \mathrm{CFU} / \mathrm{mL} \text { after } \\
\text { fermentation }\end{array}$ & {$[33]$} \\
\hline & $\begin{array}{l}\text { L.delbrueckii subsp. } \\
\text { bulgaricus }\end{array}$ & $\begin{array}{l}\text { Legume Based } \\
\text { ProductSoy Protein }\end{array}$ & $\begin{array}{l}\text { First day after fermentation } \\
54 \times 10^{6} \mathrm{CFU} / \mathrm{mL} \text {, after period of } \\
15 \text { days } 43 \times 10^{7} \mathrm{CFU} / \mathrm{mL}\end{array}$ & {$[34]$} \\
\hline & L. paracasei LBC-81 & $\begin{array}{l}\text { Cereal-Based Product } \\
\text { Maize-based substrate }\end{array}$ & Viable cell count, $10^{6} \mathrm{CFU} / \mathrm{mL}$ & [35] \\
\hline & $\begin{array}{c}\text { L. reuteri } \\
\text { NCIMB11951 }\end{array}$ & $\begin{array}{l}\text { Grain-based Product } \\
\text { Fermented beverage } \\
\text { made from oats, barley } \\
\text { or malt }\end{array}$ & $\begin{array}{l}\text { Viability between } 7.8 \text { and } 8.1 \text { log of the } \\
\text { three species in fermented beverage } \\
\text { after } 10 \mathrm{~h} \text { of fermentation at } 37^{\circ} \mathrm{C} \text {. }\end{array}$ & [36] \\
\hline & L. johnsonii & $\begin{array}{l}\text { Vegetable-Based Product } \\
\text { Traditional fermented } \\
\text { cabbage and cucumber }\end{array}$ & Above $9 \log \mathrm{CFU} / \mathrm{g}$ & {$[12,13]$} \\
\hline & B. bifidum & $\begin{array}{l}\text { Fruit-Based Product } \\
\text { Blueberry and Black } \\
\text { Berry Juices }\end{array}$ & $\begin{array}{c}\text { Increased CFU } / \mathrm{mL} \text { and } \\
7.3 \log _{10} \mathrm{CFU} / \mathrm{mL} \text { to } \\
8.2 \log _{10} \mathrm{CFU} / \mathrm{mL} \text { after } 48 \mathrm{~h} \\
\text { fermentation, }\end{array}$ & [37] \\
\hline \multirow[t]{2}{*}{$\begin{array}{l}\text { Bifidobacterium } \\
\text { strains }\end{array}$} & $\begin{array}{l}\text { B. lactis } \\
\text { Bb-12 }\end{array}$ & $\begin{array}{l}\text { Fruit-Based Product } \\
\text { Cashew apple juice }\end{array}$ & $\begin{array}{l}\text { After } 1 \text { day fermentation } \\
2.16 \times 10^{10} \mathrm{CFU} / \mathrm{L} \mathrm{h}\end{array}$ & [38] \\
\hline & $\begin{array}{c}\text { B. longum } \\
\text { Bifidobacterium longum } \\
\text { Bb-46 }\end{array}$ & $\begin{array}{l}\text { Fruit-Based Product } \\
\text { Apricot Fruit Juice }\end{array}$ & $\begin{array}{c}\text { After } 24 \mathrm{~h} \text { of fermentation were higher } \\
\text { than } 10^{8} \mathrm{CFU} / \mathrm{mL}\end{array}$ & [38] \\
\hline Saccharomyces & $\begin{array}{l}\text { Saccharomyces cerevisiae } \\
\text { CCMA 0731, }\end{array}$ & $\begin{array}{l}\text { Cereal-Based Product } \\
\text { Maize-based substrate }\end{array}$ & Viable cell counts $10^{6} \mathrm{CFU} / \mathrm{mL}$ & [35] \\
\hline Streptococcus & $\begin{array}{l}\text { Streptococcus } \\
\text { thermophiles }\end{array}$ & $\begin{array}{l}\text { Grain-based product } \\
\text { Oat Flour }\end{array}$ & Viable cell counts $10^{6} \mathrm{CFU} / \mathrm{mL}$ & {$[39]$} \\
\hline
\end{tabular}

Considering product categories, cereal- and legume-based products increase their nutritional quality by a fermentation process using lactic acid bacteria and probiotic microorganisms [44]. Cereals have a rich content of dietary fibre, carbohydrates, and vitamins. Their nondigestible carbohydrate content also helps the growth of probiotic microorganisms in the human colon such as Lactobacilli and Bifidobacteria. Microbial processes on cereals such as fermentation also affect the improvement of protein digestibility and the reduction in allergens with microbial proteases [45,46]. Moreover, water kefir increased beneficial short-chain fatty acid production at the microbial level, reduced detrimental proteolytic fermentation compounds, and increased Bifidobacterium genus abundance [47]. Vegetables and fruits are also used in the production of nondairy probiotic products. These products have excellent nutritional values due to the presence of many phytochemicals, antioxidants, zero cholesterol, vitamins, minerals, and dietary fibre [1]. Fruit and vegetable juices can improve the viability of probiotics because additional nutrients can be obtained from the raw material by cellular synthesis, which is similar to the processes used during the fermentation of fruit and vegetable juice. This may make them ideal substrates for probiotic growth. Cutting or grating vegetables and fruits also helps to release their cellular content of vitamins, minerals, sugars, and other nutrients, and creates a good environment for probiotic microbial growth [31,48]. 
It is possible to find nondairy probiotic products in the market with different combinations of food matrices $[18,26,49]$. Nondairy probiotic beverages, frozen desserts, spoonable products, and probiotic vegan milk replacements are already on the market. Nondairy probiotics and prebiotics also have a great marketing future, as recent research shows the application of strains that are well-suited to alternative matrices [42,50,51].

In recent years, plant-based dairy alternatives have received more attention due to consumer demands and environmental concerns [52]. The production of dairy products is related to environmental externalities, including greenhouse gas emissions, soil degradation from overgrazing, soil erosion, deforestation, loss of biodiversity, the contamination of surfaces and groundwater arising from waste management, and soil salinization [53]. The report of the Lancet Commission on Food, Planet, and Health explained that contemporary research concluded that vegetarian and vegan diets are associated with reductions in land use, greenhouse gas emissions, and water use [54].

There is, therefore, another motivation to develop and popularize nondairy and vegan products that are involved in reducing climate change to encourage personal actions to reduce individual carbon footprints by switching to a plant-based diet. This kind of diet also helps to prevent diet-related chronic diseases and decrease expenses $[45,55,56]$.

This growing interest in plant-based diets not only impacts sustainable consumption behaviour, but is also being noticed by the food industry [57]. Companies in the food sector need to create innovative products on market research while developing marketing skills in addition to scientific and R\&D capacity [2]. Reasonable prices and lactose-free content increase the demand for these products.

Short-term marketing strategies should focus not only on vegan consumers but also on consumers who want to reduce their consumption of animal products and are looking for new strains of nonanimal origin.

\subsection{Sensory Properties}

Acceptable sensory properties are most important in probiotic food production, and are directly related to product quality, consumer acceptability, and processing characteristics $[18,46]$. Sensory changes can occur while producing probiotic products after the probiotic bacteria had been added to raw materials. Probiotic microorganisms produce different metabolic compounds such as lactic acid during storage and fermentation. Probiotic microorganisms also ferment the raw materials' carbohydrate content, and increase alcohol content and production gases. This also affects the consumer acceptance of the product [58]. The development of nondairy probiotic products with vegetables and fruits can be undertaken in three different ways, namely, the fermentation, nonfermentation, and minimal processing of raw materials. Probiotic cultures and fermentation can also affect sensory aspects. For instance, lactic acid fermentation of fruits and vegetables enhances sensory and nutritional quality, and retains nutrients and coloured pigments [31,59]. Probiotic blackcurrant juice prepared with L. plantarum strains and blackcurrant juice have more acceptable sensory properties to consumers, such as flavour, appearance, aroma, and texture [58]. Another study regarding the fermentation of grape juice found that the sensory properties of a probiotic product prepared with Lactobacillus rhamnosus strains were highly regarded by the consumers [60].

Raw cereal grains do not have enough active organoleptic compounds with their taste and texture. This situation also affects the preferences of consumers. Fermentation can lead to reducing flavouring additives to cereals. In particular, lactic acid bacteria's enzymatic activity on cereals contributes to the taste changes, such as the sweet and sour taste generated from nonvolatile and volatile compounds [60].

Plant-based milk is one of the most common materials used to produce probiotic beverages. It has a similar appearance to animal milk but offers different sensory properties, kinetic stability, and nutrient composition. In general, plant-based milk substitutes can be defined as homogenised extracts of vegetable matrices such as cereals, vegetables, and nuts. The nutritional profile of plant-based milk alternatives is usually unbalanced, and their 
flavour profiles limit their acceptance. Probiotic fermentation was shown in several studies to improve sensory acceptability compared with unfermented alternatives [61-63].

Many researchers proved and studied that probiotic cultures did not affect the overall acceptability of the products, but these products are yet to come to the market $[61,63]$.

\section{In Vitro Assessment of Probiotic Product by Artificial Gastrointestinal Tract}

The health-promoting effects of probiotics often depend on their survival during transit through the gastrointestinal tract. To show health benefits, probiotic microorganisms should be resistant to digestion conditions and colonise in adequate amounts in the host $[64,65]$. Their survival rate depends on some factors such as galenic form, food matrix, and dosage. To prove and understand the beneficial effects and the survival of probiotic microorganisms in the host, the passage of these microorganisms must be observed throughout the gastrointestinal transit [66]. However, it is difficult to investigate this phenomenon with in vivo study. Research shows that in vitro models of the upper and lower gastrointestinal tract can provide significant insight into the behaviour of probiotic strains during digestion in humans. They are particularly relevant for screening purposes, such as for studying the effects of biopharmaceutical factors (such as dosage form, food matrix, and dose regimen) on the viability of probiotic strains throughout the human digestive tract [67].

In addition, in vivo studies can be complex and expensive to investigate microorganisms. On the other hand, in vivo probiotic research generally focuses on the recovery of beneficial microorganisms from faeces, which makes it difficult to observe probiotics' behaviour on the gastrointestinal transit. All these reasons show the importance of in vitro research in probiotic studies. Artificial digestion models are also quicker, less difficult to undertake, and have fewer ethical concerns. Research tools of artificial digestion tracts help in understanding chemical and structural changes of food components in the digestion tract parts and the gut microbiome [67].

Two different in vitro digestion models are developed, namely, static and dynamic digestion models, and they are used for research purposes. Generally, protocols for static digestion systems describe food in bioreactors where enzymatic, physical, and chemical conditions of each digestive part are recreated. However, these digestive models have limitations because digestion is a dynamic procedure. In these systems, there is no possibility to replace food between the different digestive parts, and environmental conditions such as enzymes, bile concentrations, and $\mathrm{pH}$ are stable [68].

Dynamic digestion models have better simulation advantages, such as physical conditions with constant biological and chemical changes. Generally, dynamic digestion models mimic all sections of the gastrointestinal tract for complete simulation. The main difference between dynamic digestion systems is configuration. Currently, the TNO artificial gastrointestinal model with specific variations (TIM-agc, tinyTIM, TIM-1, TIM2) is used [62]. The mainly used generic platform is TIM-1, which includes the stomach, duodenum, jejunum, and ileum. These four compartments are connected with peristaltic valve pumps. This configuration has several variants for animals and humans for different kinds of meals. TinyTIM does not include separate intestinal steps and is a more basic version of TIM. TIM-agc is a more qualified version of TIM systems and it helps to compare the compounds of digestion under controlled conditions. As it is possible to observe the movement of foods and drugs, the design of this version enables a more accurate assessment of the behaviour of the stomach [57].

Another currently used dynamic digestive system is the Simulator of Human Intestinal Microbial Ecosystem (SHIME ${ }^{\circledR}$ ) model, which is a computer-controlled gastrointestinal simulation device. It is possible to examine the microbial ecology and physiology of the gastrointestinal system. The model allows for simulating various age groups and some diseases. The simulator consists of five different reactors that help to see parts of the gastrointestinal system, the stomach, the ileum, and three parts of the colon (ascendant, transversal, and descendent). First, reactors allow for simulating steps of food intake 
and digestion with fill and drawing reactor. The peristaltic pumps, SHIME ${ }^{\circledR}$ nutritional medium, pancreatic enzymes, and bile liquid set off physiological conditions in the large intestine $[69,70]$. The model also maintains microbiota stability for a determined time and helps to observe the adaptation of microbiota. The different subjects can also be examined at the same time and the subject's microbiome can be stored to set up unique features. The Mucus SHIME ${ }^{\circledR}$ is the specific variation of the SHIME ${ }^{\circledR}$ model. The model is used for the investigation of the adhesion ability of bacteria and changes in the microbiome in the mucosal parts of the gastrointestinal system [71].

For instance, the following studies were conducted on in vitro digestion models. Lactobacillus crispatus strain, added to cheese as a probiotic culture and isolated from a healthy human vaginal environment, was tested for its digestion system process using $\mathrm{SHIME}^{\circledR}$. Results showed that the survival of L. cripatus BC4 was not affected by gastric digestion, but was significantly affected by bile salts and pancreatic juice. During colon simulation, L. cripatus BC4 was able to grow under sterile colon conditions and survive in the presence of a complex microbiota [72]. Another study also investigated soybean polysaccharides' bioavailability and the metabolites on the gut microbiota by using SHIME. Results showed that soybean polysaccharides were only partially decreased in the oral, gastric, and small intestine parts of SHIME [73].

Increasing our understanding of probiotic behaviours in the product and during gastrointestinal passage is crucial in the development of nondairy probiotic food. This may be efficiently achieved by utilising available in vitro digestion systems that reliably recapitulate the in vivo situation without introducing any ethical concerns.

\section{Conclusions}

The potential health benefits of probiotics have been illustrated by many studies. Most of the functional foods containing those beneficial microorganisms are from dairy sources. However, the high fat, cholesterol, lactose, or allergen content of dairy products may induce health problems and cause the exclusion of valuable functional foods from the diet. One of the solutions to this problem may be products containing probiotics produced from nondairy raw materials. The value and benefit of the probiotics themselves, combined with raw plant materials, give rise to unique advantages, for example, additional content of fibre or phytochemicals with quality sensory properties.

There is a market gap in the supply of the discussed nutritious food, especially for people who are unable or unwilling to eat dairy products. To address this issue, there is a need to intensify the indepth research and development of nondairy probiotic foods. In particular, advances in product evaluation through in vitro digestion models lead to faster and more accurate data on the health value of the product. In vitro artificial digestion systems are reliable, and this research methodology has no ethical concerns.

In addition, paying attention to nondairy and vegan foods benefits the environment by reducing land use, greenhouse gas emissions, and water consumption compared to the production of raw dairy materials.

Author Contributions: Conceptualization, K.K. and M.T.; methodology, K.K. and M.T., resources, K.K. and M.T.; writing—original draft preparation, K.K.; writing—review and editing M.T.; supervision, M.T. All authors have read and agreed to the published version of the manuscript.

Funding: The APC was funded by the Institute of Human Nutrition Sciences and the Doctoral School SGGW.

Institutional Review Board Statement: Not applicable.

Informed Consent Statement: Not applicable.

Data Availability Statement: Not applicable.

Conflicts of Interest: The authors declare no conflict of interest. 


\section{References}

1. Panghal, A.; Janghu, S.; Virkar, K.; Gat, Y.; Kumar, V.; Chhikara, N. Potential Non-Dairy Probiotic Products-A Healthy Approach. Food Biosci. 2018, 21, 80-89. [CrossRef]

2. Rosi, A.; Mena, P.; Pellegrini, N.; Turroni, S.; Neviani, E.; Ferrocino, I.; Di Cagno, R.; Ruini, L.; Ciati, R.; Angelino, D.; et al Environmental Impact of Omnivorous, Ovo-Lacto-Vegetarian, and Vegan Diet. Sci. Rep. 2017, 7, 6105. [CrossRef]

3. Hill, C.; Guarner, F.; Reid, G.; Gibson, G.R.; Merenstein, D.J.; Pot, B.; Morelli, L.; Canani, R.B.; Flint, H.J.; Salminen, S.; et al. The International Scientific Association for Probiotics and Prebiotics Consensus Statement on the Scope and Appropriate Use of the Term Probiotic. Nat. Rev. Gastroenterol. Hepatol. 2014, 11, 506-514. [CrossRef] [PubMed]

4. Saarela, M.; Alakomi, H.L.; Mättö, J.; Ahonen, A.M.; Puhakka, A.; Tynkkynen, S. Improving the storage stability of Bifidobacterium breve in low $\mathrm{pH}$ fruit juice. Int. J. Food Microbiol. 2011, 149, 106-110. [CrossRef] [PubMed]

5. Perricone, M.; Bevilacqua, A.; Altieri, C.; Sinigaglia, M.; Corbo, M.R. Challenges for the Production of Probiotic Fruit Juices. Beverages 2015, 1, 95-103. [CrossRef]

6. Markowiak, P.; Śliżewska, K. Effects of Probiotics, Prebiotics, and Synbiotics on Human Health. Nutrients 2017, 9, 1021. [CrossRef]

7. Liu, Y.; Tran, D.Q.; Rhoads, J.M. Probiotics in Disease Prevention and Treatment. J. Clin. Pharmacol. 2018, 58, S164-S179. [CrossRef]

8. Ryma, T.; Samer, A.; Soufli, I.; Rafa, H.; Touil-Boukoffa, C. Role of Probiotics and Their Metabolites in Inflammatory Bowel Diseases (IBDs). Gastroenterol. Insights 2021, 12, 6. [CrossRef]

9. Da Pontes, K.S.S.; Guedes, M.R.; da Cunha, M.R.; de Mattos, S.S.; Barreto Silva, M.I.; Neves, M.F.; Marques, B.C.A.A.; Klein, M.R.S.T. Effects of Probiotics on Body Adiposity and Cardiovascular Risk Markers in Individuals with Overweight and Obesity: A Systematic Review and Meta-Analysis of Randomized Controlled Trials. Clin. Nutr. 2021, 40, $4915-4931$. [CrossRef]

10. Abbasi, A.; Aghebati-Maleki, A.; Yousefi, M.; Aghebati-Maleki, L. Probiotic Intervention as a Potential Therapeutic for Managing Gestational Disorders and Improving Pregnancy Outcomes. J. Reprod. Immunol. 2021, 143, 103244. [CrossRef]

11. De Brito Alves, J.L.; de Oliveira, Y.; Carvalho, N.N.C.; Cavalcante, R.G.S.; Pereira Lira, M.M.; do Nascimento, L.C.P.; Magnani, M.; Vidal, H.; de Braga, V.A.; de Souza, E.L. Gut Microbiota and Probiotic Intervention as a Promising Therapeutic for Pregnant Women with Cardiometabolic Disorders: Present and Future Directions. Pharmacol. Res. 2019, 145, 104252. [CrossRef] [PubMed]

12. Zielińska, D.; Rzepkowska, A.; Radawska, A.; Zieliński, K. In Vitro Screening of Selected Probiotic Properties of Lactobacillus Strains Isolated from Traditional Fermented Cabbage and Cucumber. Curr. Microbiol. 2015, 70, 183-194. [CrossRef] [PubMed]

13. Zielińska, D.; Długosz, E.; Zawistowska-Deniziak, A. Functional Properties of Food Origin Lactobacillus in the Gastrointestinal Ecosystem-In Vitro Study. Probiotics Antimicrob. Proteins 2019, 11, 820-829. [CrossRef] [PubMed]

14. Aspri, M.; Papademas, P. Review on Non-Dairy Probiotics and Their Use in Non-Dairy Based Products. Fermentation 2020, 6, 30. [CrossRef]

15. Fijan, S. Microorganisms with Claimed Probiotic Properties: An Overview of Recent Literature. Int. J. Environ. Res. Public Health 2014, 11, 4745-4767. [CrossRef] [PubMed]

16. Ilango, S.; Antony, U. Probiotic Microorganisms from Non-Dairy Traditional Fermented Foods. Trends Food Sci. Technol. 2021, 118, 617-638. [CrossRef]

17. Meybodi, N.M.; Mortazavian, A.M.; Arab, M.; Nematollahi, A. Probiotic viability in yoghurt: A review of influential factors. Int Dairy J. 2020, 109, 104793. [CrossRef]

18. Shori, A.B. Influence of Food Matrix on the Viability of Probiotic Bacteria: A Review Based on Dairy and Non-Dairy Beverages. Food Biosci. 2016, 13, 1-8. [CrossRef]

19. Chaturvedi, S.; Khartad, A.; Chakraborty, S. The potential of non-dairy synbiotic instant beverage powder: Review on a new generation of healthy ready-to-reconstitute drinks. Food Biosci. 2021, 42, 101195. [CrossRef]

20. Zhu, W.; Lyu, F.; Naumovski, N.; Ajlouni, S.; Ranadheera, C.S. Functional Efficacy of Probiotic Lactobacillus Sanfranciscensis in Apple, Orange and Tomato Juices with Special Reference to Storage Stability and In Vitro Gastrointestinal Survival. Beverages 2020, 6, 13. [CrossRef]

21. Rouissi, A.; Alfonso-Avila, A.R.; Guay, F.; Boulianne, M.; Létourneau-Montminy, M.P. Effects of Bacillus subtilis, butyrate, mannan-oligosaccharide, and naked oat (ß-glucans) on growth performance, serum parameters, and gut health of broiler chickens. Poultry Sci. 2021, 100, 101506. [CrossRef] [PubMed]

22. Abdi, R.; Joye, I.J. Prebiotic Potential of Cereal Components. Foods 2021, 10, 2338. [CrossRef] [PubMed]

23. Lazaridou, A.; Serafeimidou, A.; Biliaderis, C.G.; Moschakis, T.; Tzanetakis, N. Structure Development and Acidification Kinetics in Fermented Milk Containing Oat $\beta$-Glucan, a Yogurt Culture and a Probiotic Strain. Food Hydrocoll. 2014, 39, 204-214. [CrossRef]

24. Qiu, X.J.; Zheng, W.X.; Zhang, L.; Shi, Y.L.; Hu, J.H.; Li, Y.L.; Liu, Z.Y.; Zhu, M.D. Prebiotic Effects of Xylanase Modification Of $\beta$-Glucan from Oat Bran on Bifidobacterium Bifidum. Ital. J. Food Sci. 2020, 32, 6-17. [CrossRef]

25. Lillo-Pérez, S.; Guerra-Valle, M.; Orellana-Palma, P.; Petzold, G. Probiotics in Fruit and Vegetable Matrices: Opportunities for Nondairy Consumers. LWT 2021, 151, 112106. [CrossRef]

26. Vanajakshi, V.; Vijayendra, S.V.N.; Varadaraj, M.C.; Venkateswaran, G.; Agrawal, R. Optimization of a Probiotic Beverage Based on Moringa Leaves and Beetroot. LWT_Food Sci. Technol. 2015, 63, 1268-1273. [CrossRef]

27. Barbu, V.; Cotârleț, M.; Bolea, C.A.; Cantaragiu, A.; Andronoiu, D.G.; Bahrim, G.E.; Enachi, E. Three Types of Beetroot Products Enriched with Lactic Acid Bacteria. Foods 2020, 9, 786. [CrossRef] [PubMed] 
28. Sengun, I.Y.; Kirmizigul, A.; Atlama, K.; Yilmaz, B. Viability of Lactobacillus Rhamnosus in Orange Juice Fortified with Nettle (Urtica dioica L.) and Bioactive Properties of the Juice during Storage. LWT 2020, 118, 108707. [CrossRef]

29. Almada-Érix, C.N.; Almada, C.N.; Cabral, L.; Barros de Medeiros, V.P.; Roquetto, A.R.; Santos-Junior, V.A.; Fontes, M.; Gonçalves, A.E.S.S.; Dos Santos, A.; Lollo, P.C.; et al. Orange Juice and Yogurt Carrying Probiotic Bacillus Coagulans GBI30 6086: Impact of Intake on Wistar Male Rats Health Parameters and Gut Bacterial Diversity. Front. Microbiol. 2021, $12,623951$. [CrossRef]

30. Swain, M.R.; Anandharaj, M.; Ray, R.C.; Parveen Rani, R. Fermented Fruits and Vegetables of Asia: A Potential Source of Probiotics. Biotechnol. Res. Int. 2014, 2014, 250424. [CrossRef] [PubMed]

31. Noorbakhsh, R.; Yaghmaee, P.; Durance, T. Radiant Energy under Vacuum (REV) Technology: A Novel Approach for Producing Probiotic Enriched Apple Snacks. J. Funct. Foods 2013, 5, 1049-1056. [CrossRef]

32. Russo, P.; Peña, N.; de Chiara, M.L.V.; Amodio, M.L.; Colelli, G.; Spano, G. Probiotic Lactic Acid Bacteria for the Production of Multifunctional Fresh-Cut Cantaloupe. Food Res. Int. 2015, 77, 762-772. [CrossRef]

33. Wang, Z.; Feng, Y.; Yang, N.; Jiang, T.; Xu, H.; Lei, H. Fermentation of kiwifruit juice from two cultivars by probiotic bacteria: Bioactive phenolics, antioxidant activities and flavor volatiles. Food Chem. 2022, 373, 131455. [CrossRef] [PubMed]

34. Vaishanavi, S.; Preetha, R. Soy protein incorporated nanoemulsion for enhanced stability of probiotic (Lactobacillus delbrueckii subsp. bulgaricus) and its characterization. Mater. Today Proc. 2021, 40, S148-S153. [CrossRef]

35. Menezes, A.G.T.; Ramos, C.L.; Dias, D.R.; Schwan, R.F. Combination of probiotic yeast and lactic acid bacteria as starter culture to produce maize-based beverages. Food Res. Int. 2018, 111, 187-197. [CrossRef] [PubMed]

36. Salmerón, I.; Thomas, K.; Pandiella, S.S. Effect of Potentially Probiotic Lactic Acid Bacteria on the Physicochemical Composition and Acceptance of Fermented Cereal Beverages. J. Funct. Foods 2015, 15, 106-115. [CrossRef]

37. Wu, Y.; Li, S.; Tao, Y.; Li, D.; Han, Y.; Show, P.L.; Wen, G.; Zhou, J. Fermentation of blueberry and blackberry juices using Lactobacillus plantarum, Streptococcus thermophilus and Bifidobacterium bifidum: Growth of probiotics, metabolism of phenolics, antioxidant capacity in vitro and sensory evaluation. Food Chem. 2021, 348, 129083. [CrossRef]

38. Bujna, E.; Farkas, N.A.; Tran, A.M.; Dam, M.S.; Nguyen, Q.D. Lactic acid fermentation of apricot juice by mono- and mixed cultures of probiotic Lactobacillus and Bifidobacterium strains. Food Sci. Biotechnol. 2018, 27, 547-554. [CrossRef]

39. Duru, K.C.; Kovaleva, E.G.; Danilova, I.G.; Belousova, A.V. Production and assessment of novel probiotic fermented oat flour enriched with isoflavones. LWT 2019, 111, 9-15. [CrossRef]

40. Craig, W.J.; Brothers, C.J. Nutritional Content and Health Profile of Non-Dairy Plant-Based Yogurt Alternatives. Nutrients 2021, 13, 4069. [CrossRef] [PubMed]

41. Duda-Chodak, A.; Tarko, T.; Satora, P.; Sroka, P. Interaction of Dietary Compounds, Especially Polyphenols, with the Intestinal Microbiota: A Review. Eur. J. Nutr. 2015, 54, 325-341. [CrossRef]

42. Gawkowski, D.; Chikindas, M.L. Non-Dairy Probiotic Beverages: The next Step into Human Health. Benef. Microbes 2013, 4 127-142. [CrossRef]

43. Guan, R.; Van Le, Q.; Yang, H.; Zhang, D.; Gu, H.; Yang, Y.; Sonne, C.; Lam, S.S.; Zhong, J.; Jianguang, Z.; et al. A Review of Dietary Phytochemicals and Their Relation to Oxidative Stress and Human Diseases. Chemosphere 2021, 271, 129499. [CrossRef]

44. Setta, M.C.; Matemu, A.; Mbega, E.R. Potential of probiotics from fermented cereal-based beverages in improving health of poor people in Africa. J. Food Sci. Technol. 2020, 57, 3935-3946. [CrossRef] [PubMed]

45. Mridula, D.; Sharma, M. Development of non-dairy probiotic drink utilizing sprouted cereals, legume and soymilk. LWT-Food Sci. Technol. 2015, 62, 482-487. [CrossRef]

46. Cosme, F.; Inês, A.; Vilela, A. Consumer's Acceptability and Health Consciousness of Probiotic and Prebiotic of Non-Dairy Products. Food Res. Int. 2022, 151, 110842. [CrossRef] [PubMed]

47. Calatayud, M.; Börner, R.A.; Ghyselinck, J.; Verstrepen, L.; Medts, J.D.; den Abbeele, P.V.; Boulangé, C.L.; Priour, S.; Marzorati, M.; Damak, S. Water Kefir and Derived Pasteurized Beverages Modulate Gut Microbiota, Intestinal Permeability and Cytokine Production In Vitro. Nutrients 2021, 13, 3897. [CrossRef] [PubMed]

48. Tsafrakidou, P.; Michaelidou, A.M.; Biliaderis, C.G. Fermented Cereal-Based Products: Nutritional Aspects, Possible Impact on Gut Microbiota and Health Implications. Foods 2020, 9, 734. [CrossRef] [PubMed]

49. Pimentel, T.C.; Gomes de Oliveira, L.I.; de Lourdes Chaves Macedo, E.; Costa, G.N.; Dias, D.R.; Schwan, R.F.; Magnani, M. Understanding the Potential of Fruits, Flowers, and Ethnic Beverages as Valuable Sources of Techno-Functional and Probiotics Strains: Current Scenario and Main Challenges. Trends Food Sci. Technol. 2021, 114, 25-59. [CrossRef]

50. Pimentel, T.C.; Gomes de Oliveira, L.I.; Carvalho de Souza, R.; Magnani, M. Probiotic Non-Dairy Frozen Dessert: Technological and Sensory Aspects and Industrial Challenges. Trends Food Sci. Technol. 2021, 107, 381-388. [CrossRef]

51. Väkeväinen, K.; Ludena-Urquizo, F.; Korkala, E.; Lapveteläinen, A.; Peräniemi, S.; von Wright, A.; Plumed-Ferrer, C. Potential of Quinoa in the Development of Fermented Spoonable Vegan Products. LWT 2020, 120, 108912. [CrossRef]

52. Schiano, A.N.; Harwood, W.S.; Gerard, P.D.; Drake, M.A. Consumer perception of the sustainability of dairy products and plant-based dairy alternatives. J. Dairy Sci. 2020, 103, 11228-11243. [CrossRef] [PubMed]

53. Saari, U.A.; Herstatt, C.; Tiwari, R.; Dedehayir, O.; Mäkinen, S.J. The Vegan Trend and the Microfoundations of Institutional Change: A Commentary on Food Producers' Sustainable Innovation Journeys in Europe. Trends Food Sci. Technol. 2021, 107, 161-167. [CrossRef] 
54. Willett, W.; Rockström, J.; Loken, B.; Springmann, M.; Lang, T.; Vermeulen, S.; Garnett, T.; Tilman, D.; DeClerck, F.; Wood, A.; et al. Food in the Anthropocene: The EAT-Lancet Commission on Healthy Diets from Sustainable Food Systems. Lancet 2019, 393, 447-492. [CrossRef]

55. Buchs, M.; Saunders, C.; Wallbridge, R.; Smith, G.; Bardsley, N. Identifying and Explaining Framing Strategies of Low Carbon Lifestyle Movement Organisations. Glob. Environ. Chang. 2015, 35, 307-315. [CrossRef]

56. Bryant, C.J. We Can't Keep Meating Like This: Attitudes towards Vegetarian and Vegan Diets in the United Kingdom. Sustainability 2019, 11, 6844. [CrossRef]

57. Dupont, D.; Alric, M.; Blanquet-Diot, S.; Bornhorst, G.; Cueva, C.; Deglaire, A.; Denis, S.; Ferrua, M.; Havenaar, R.; Lelieveld, J.; et al. Can Dynamic in Vitro Digestion Systems Mimic the Physiological Reality? Crit. Rev. Food Sci. Nutr. 2019, 59, $1546-1562$. [CrossRef] [PubMed]

58. Mohammadi, R.; Mortazavian, A.; Khosrokhavar, R. Probiotic Ice Cream: Viability of Probiotic Bacteria and Sensory Properties. Ann. Microbiol. 2011, 61, 411-424. [CrossRef]

59. Sridharan, S.; Das, K.M.S. A Study on Suitable Non Dairy Food Matrix for Probiotic Bacteria Seanstematic Review. Curr. Res. Nutr. Food Sci. J. 2019, 7, 5-16. [CrossRef]

60. Malganji, S.; Sohrabvandi, S.; Jahadi, M.; Nematollahi, A.; Sarmadi, B. Effect of Refrigerated Storage on Sensory Properties and Viability of Probiotic in Grape Drink. Appl. Food Biotechnol. 2016, 3, 59-62. [CrossRef]

61. Peyer, L.; Zannini, E.; Arendt, E. Lactic Acid Bacteria as Sensory Biomodulators for Fermented Cereal-Based Beverages. Trends Food Sci. Technol. 2016, 54, 17-25. [CrossRef]

62. Aydar, E.F.; Tutuncu, S.; Ozcelik, B. Plant-based milk substitutes: Bioactive compounds, conventional and novel processes, bioavailability studies, and health effects. J. Funct. Foods 2020, 70, 103975. [CrossRef]

63. Bocker, R.; Silva, E.K. Innovative technologies for manufacturing plant-based non-dairy alternative milk and their impact on nutritional, sensory and safety aspects. Future Foods 2022, 5, 100098. [CrossRef]

64. Rasika, D.M.; Vidanarachchi, J.K.; Rocha, R.S.; Balthazar, C.F.; Cruz, A.G.; Sant'Ana, A.S.; Ranadheera, C.S. Plant-based milk substitutes as emerging probiotic carriers. Curr. Opin. Food Sci. 2021, 38, 8-20. [CrossRef]

65. Dodoo, C.C.; Wang, J.; Basit, A.W.; Stapleton, P.; Gaisford, S. Targeted Delivery of Probiotics to Enhance Gastrointestinal Stability and Intestinal Colonisation. Int. J. Pharm. 2017, 530, 224-229. [CrossRef] [PubMed]

66. Singh, G.; Haileselassie, Y.; Briscoe, L.; Bai, L.; Patel, A.; Sanjines, E.; Hendler, S.; Singh, P.K.; Garud, N.R.; Limketkai, B.N.; et al. The Effect of Gastric Acid Suppression on Probiotic Colonization in a Double Blinded Randomized Clinical Trial. Clin. Nutr. ESPEN 2021, 47, 70-77. [CrossRef] [PubMed]

67. Hassan, I.; Gani, A.; Ul Ashraf, Z. Chapter 3-Simulated Gastrointestinal System to Assess the Probiotic Properties Modified to Encapsulation of Probiotics and Their Survival Under Simulated Gastrointestinal System. In Advances in Probiotics; Dhanasekaran, D., Sankaranarayanan, A., Eds.; Academic Press: Cambridge, MA, USA, 2021; pp. 37-44. ISBN 978-0-12-822909-5.

68. Liu, W.; Fu, D.; Zhang, X.; Chai, J.; Tian, S.; Han, J. Development and Validation of a New Artificial Gastric Digestive System. Food Res. Int. 2019, 122, 183-190. [CrossRef] [PubMed]

69. Minekus, M. The TNO Gastro-Intestinal Model (TIM). In The Impact of Food Bioactives on Health: In Vitro and Ex Vivo Models; Verhoeckx, K., Cotter, P., López-Expósito, I., Kleiveland, C., Lea, T., Mackie, A., Requena, T., Swiatecka, D., Wichers, H., Eds.; Springer: Cham, Switzerland, 2015; ISBN 978-3-319-15791-7.

70. Van de Wiele, T.; Van den Abbeele, P.; Ossieur, W.; Possemiers, S.; Marzorati, M. The Simulator of the Human Intestinal Microbial Ecosystem (SHIME ${ }^{\circledR}$ ). In The Impact of Food Bioactives on Health: In Vitro and Ex Vivo Models; Verhoeckx, K., Cotter, P., López-Expósito, I., Kleiveland, C., Lea, T., Eds.; Springer: Cham, Switzerland, 2015; ISBN 978-3-319-15791-7.

71. Giuliani, C.; Marzorati, M.; Innocenti, M.; Vilchez-Vargas, R.; Vital, M.; Pieper, D.H.; Van de Wiele, T.; Mulinacci, N. Dietary Supplement Based on Stilbenes: A Focus on Gut Microbial Metabolism by the in Vitro Simulator M-SHIME ${ }^{\circledR}$. Food Funct. 2016, 7, 4564-4575. [CrossRef]

72. Patrignani, F.; Parolin, C.; D'Alessandro, M.; Siroli, L.; Vitali, B.; Lanciotti, R. Evaluation of the Fate of Lactobacillus Crispatus BC4, Carried in Squacquerone Cheese, throughout the Simulator of the Human Intestinal Microbial Ecosystem (SHIME). Food Res. Int. 2020, 137, 109580. [CrossRef]

73. Chen, P.; Chen, X.; Hao, L.; Du, P.; Li, C.; Han, H.; Xu, H.; Liu, L. The Bioavailability of Soybean Polysaccharides and Their Metabolites on Gut Microbiota in the Simulator of the Human Intestinal Microbial Ecosystem (SHIME). Food Chem. 2021, 362, 130233. [CrossRef] [PubMed] 